受賞者総説

\title{
サワラの生活史初期における摂食戦略と資源加入機構に関する研究
}

\author{
(平成 16 年度日本水産学会賞奨励賞受賞)
}

\author{
小路淳* \\ 京都大学フィールド科学教育研究センター河口域生態学分野 \\ Studies on feeding strategy during the early life stages and recruitment mechanism of \\ Japanese Spanish mackerel Scomberomorus niphonius \\ JUN SHOJI* \\ Laboratory of Estuarine Ecology, Field Science Education and Research Center, \\ Kyoto University, Kitashirakawa, Sakyo, Kyoto 606-8502, Japan
}

魚類の浮遊生活期は, 生活史のなかで死亡率がも高い 時期である。1) 魚食性の早期発現は魚類の幼期個体に高 成長をもたらし，死亡率の高い生活史初期を短期間でく ぐり抜け高い生残率を得ることを可能にする生残戦略と 考えられている。2)しかしその一方で，魚食性仔稚魚は 無脊椎動物プランクトンに比べて分布密度がきわめて低 い魚類 3,4 を主要䬣料生物とするために, より大きなエ ネルギーを索餌のために要する。したがって，魚類とい う限られた飭料生物の分布密度の変動により, 成長や生 残が大きく左右される, いわば高成長・高死亡が隣り合 わせの生活史初期を魚食性仔稚魚が過ごしていると言え る。

㨟餌開始期から魚類のみを専食するサワラは，このよ うな「魚食戦略」の典型種である。 て速い一方で, 7) 魚類という少ない慨料に依存するため に, 生活史初期における飢餓による死亡の危険がきわめ て高い。8)このような生活史特性を持つサワラでは, 摂 餌開始期に好適な餌料生物環境に遭遇するかどうかが, その後の成長や生残に非常に強く影響する。これまで, 餌料生物の出現との時間的一致が魚類の初期生残・加入 の規定要因であるとする「Match-mismatch Hypothesis $\lrcorner^{9}$ は, 浮遊生活期に無脊椎動物プランクトンを主食 とする魚類に適用されてきた。本研究では, 瀬戸内海に おけるフィールド調查と飼育実験によりサワラの生活史 初期における生理・生態学的知見を蓄積するとともに, 初期から強い魚食性を示すサワラの加入決定機構を $\lceil$ Match-mismatch Hypothesis」により説明できる可能 性を示した。
1. 仔稚魚の摂餌生態：非常に強い魚食性 魚食性魚類 の多くは仔魚期に無脊椎動物プランクトンを主食とし, 仔魚期の後期もしくは稚魚期以降に魚食性へと移行す る。2,3)これらとは対照的に, サワラは揸餌開始期から魚 類を専食する。サワラ仔魚の消化管内容物の $95 \%$ （個 体数割合）以上を占める魚類のうち, カタクチイワシ等 のニシン目仔魚が最も多く捕食されている。10,11) サワラ のように摂餌開始期から完全に魚食性を示す種は極めて 例外的であり, 同科のサバ科に属するカツオ・マグロ類 やマサバにおいても, 魚食性はより後になってから発現 する。5,12,13) な打, 強い魚食性を示すサワラ仔稚魚の天 然海域に抢ける共食い個体の出現割合は多い年でも 1 $\%$ 程度の低い值であった。 ${ }^{10,11)}$

サワラの強い魚食性が環境要因により発現するもので はなく，魚類を選択的に捕食した結果であることを実験

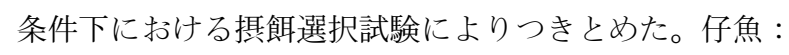
無脊椎動物プランクトン比を $1: 6000$ に設定した水槽 に抢いて, サワラは仔魚に対して強い選択性を示し た。 さららに,ヒラメ仔魚とコノシロ（ニシン目）仔魚 が同数ずつ存在する水槽内では, コノシロ仔魚を高い割 合で捕食した。14)

サワラは比較的大きな卵 $(1.35 \sim 1.85 \mathrm{~mm})$ から方化 する。摂䬳開始期の全長（約 $6 \mathrm{~mm}$ ) は, マサバ, クロ マグロ等の他のサバ科仔魚 (約 $4 \mathrm{~mm}$ ) やサワラ仔魚の 主要飭料生物であるカタクチイワシ仔魚 $(3.7 \mathrm{~mm})$ に 比べて大きく, 分離浮性卵を産する海産魚類の中で非常 に大きい。15-18)

一般に魚食性魚類では自らの体長の $50 \%$ 以下の魚類

* Tel : 81-75-753-6225. Fax : 81-75-753-6229. Email : shog@kais.kyoto-u.ac.jp 
を捕食する場合が多く，この比を上回る䬣料生物に対す る捕食成功率は極めて低くなる。19) しかし, サワラ仔稚 魚の胃内容物のほとんどは体長の 50〜 100\%の範囲で あり, 魚食性魚類の中でもとりわけ捕食対象のサイズが 大きい。20) カタクチイワシのように体型が細長く遊泳能 力に乏しい魚類が， サワラの仔稚魚期を通じ長期間重要 な飷料生物として利用されている。

\section{2. 魚類トップクラスの成長率と死亡率}

魚類の浮遊生活期の長さは魚種間で大きく異なる。 94 種の硬骨魚類の平均浮遊期間は 33.1 日であり, なか には 550 日以上の浮遊生活期を送る種も存在する。 ${ }^{21,22)}$ サワラ仔稚魚の成長速度は $1 \mathrm{~mm} / \mathrm{d}$ を上回り, 速い個 体では子化後 1 ヶ月で全長 $100 \mathrm{~mm}$ に達する。 ${ }^{11,17)}$ 体長 約 $4 \mathrm{~mm}$ で孵化し, ${ }^{15,16)}$ 約 $12 \mathrm{~mm}$ で仔魚から稚魚へと 移行する23) サワラの浮遊生活期間は 10 日以内であり, 魚類の中でほぼ最短の浮遊生活期である。

サワラ仔稚魚は日中に摂慨を行う daylight feeder で ある。20,24) フィールド抢よび実験条件下に打いて求めた サワラ仔魚の日間摂食量（体重比\%）は，90１28\% で あった。この值は，ミナミマグロ, 12) マサバ25)などのサ 八゙科仔魚に抢ける推定値に比べて高い。高い掑食量がサ ワラ仔稚魚の高成長を支える要因の一つであると考えら れる。

成長率が高い一方で, サワラの初期死亡率も極めて高 い。26)一般に魚類の生活史初期に打ける死亡係数は水温 の関数で表され, 高水温域に生息する魚種で高い傾向が ある。 ${ }^{21,22)}$ 温帯性種であるサワラの生息水温は熱帯性魚 類に比べて低く約 $18 \sim 22^{\circ} \mathrm{C}$ である。 数は $0.63 \sim 0.78$ に達し 26 ) 魚類の中でほぼ最高值に匹敵 する (33 種の平均は 0.22$) 。{ }^{21,22)}$

このような高い死亡率を引き起こす要因は何か？一 般に魚類の初期減耗要因として被食が最も重要と考えら れているが, 1) サワラでは, 飢餓や, 飢餓が根元的要因 となって生じる被食が主要な減耗要因と考えられてい る。 8 ,28) 実験条件下で求めたサワラの無給慨生残限界は 約 1 日と非常に短く, さらに, 飢餓を経験した後の成 長回復が鈍いことも明らかになった。8）とりわけ摂慨開 始直後に飢餓を経験した個体において, 給慨再開後の成 長遅滞が顕著となる。すなわち, 摂餌開始期に好適な餌 料生物環境に遭遇することが，サワラの順調な成長や生 残にきわめて重要であることを示している。

海洋に打ける仔魚飭料の分布密度はカイアシ類などの 無脊椎動物プランクトンに比べて極めて低い。年) 実験条 件下で求めたサワラ仔稚魚の巡航遊泳速度はマダイ, ヒ ラメ29)などの他の海産仔稚魚に比べて極めて高かっ た。30)この結果は, 魚食という特化した摂食生態をもつ サワラが, 低密度な仔魚䭒料を求めて広範囲を遊泳し,
摂䬣のために高いエネルギーを費やしていることを示 す。

\section{3. 生残メカニズム：早期に生じる成長選択的生残}

高成長を示す一方で飢餓に対する耐性が低いサワラで は, 生残のプロセスが 2 分化され易い。8)すなわち, 好 適な飭料環境に遭遇し高成長をとげて生残するか, 好適 な飭料環境に恵まれず成長が停滞するとともに慨餓や被 食により死亡するかの 2 者択一的プロセスがサワラの 生活史初期に顕在化する。魚食性を示す仔稚魚の中で も, マサバのように無脊椎動物プランクトン食と魚食の 2 つの摂食戦略のスイッチングが可能な種では, 13,31$)$ 遭 遇した飭料生物環境に応じて摃食対象を柔軟に変更し, その成長過程は多様化しうる。これに対し, サワラでは 無脊椎動物プランクトンに依存して生残することは不可 能であるため，低成長を遂げる個体はほとんど生残でき ず，仔魚䬣料を捕食し続けて高成長をとげた個体の久が 生き残るという，二極化した生残プロセスが顕在化す る。このような仮説をフィールドにおいて実証した。

瀬戸内海中央部に打いて繰り返しサンプリングを行 い, 同一ふ化日コホートからなるサワラ仔稚魚の成長履 歴を解析し, 仔魚 ( $<12 \mathrm{~mm}$ : 初期群) と稚魚 ( > 12 $\mathrm{mm}$ : 生残群）の摂䬣開始期における成長速度を逆算推 定した。子化後 8 日（㨟䬲開始 3 日）までに両群間の 成長差がひろがり, 摂飭開始直後に高成長をとげた個体 が高い確率で稚魚期まで生き残っていることが示され た。このような成長選択的生残は, ニシン・タラ類等の 魚種に比べてサワラでは極めて早期に明瞭化する。32)さ らに, 䭒料生物密度が高かった年には初期群の成長が高 く, 高成長群への選択が弱まる。以上の結果は, サワラ の生残プロセスが慨料生物環境の影響を受けつつ高成長 もしくは死亡へと 2 極化するという先述の仮説を裏づ けるものである。さらに, 生まれて間もないふ化後 8 日（摂慨開始 3 日）間に遭遇する䭒料生物環境が初期 生残の決め手となることを示している。

\section{4. 加入機構 : 摂餌開始期における「Match」の意義}

瀬戸内海中央部に打政ワラの産卵盛期は, 魚類プ ランクトンの分布密度が 1 年のうちで最も高くなる 5 月に一致する。 めうる産卵戦略をサワラが発達させてきたことを示唆す る。 ${ }^{27)}$ 摂䬣開始期における仔魚と慨料生物の出現の時間 的一致により加入が決まるという「Match-mismatch Hypothesis 」9) をサワラの加入決定機構に適用できるか ぞうかを野外データに基づいて検討した。

サワラの主産卵場の一つである瀬戸内海中央部遂灘に 打ける仔魚と稚魚の分布密度に相関は認められないもの の, 稚魚と翌年に漁獲される 1 歳魚の分布密度の間に 
は正の相関関係が認められた。23,36)この結果は, 仔魚期 における生残の年変動は大きいが，稚魚期から満 1 歳 の間の生残は比較的安定していることを示す。さらに, 稚魚期の初期（ふ化後 10 日，体長 $12 \mathrm{~mm}$ ） までの生き 残りが年級強度に反映されることを示している。

サワラ仔魚と初期餌料生物（ニシン目仔魚）の出現動 態は年間で大きく異なった。サワラ仔魚の発生量は加入 豊度に必ずしも対応しなかった。例えば，1997 年には 仔魚発生量が最高であったが加入は最低であった。この ような年には初期餌料生物の密度が極めて低い「Mismatch」の状態を仔魚が経験し, その成長速度も低かっ た。26,37)これとは対照的に, 卓越年級群が発生した 1995 年と 1999 年には産卵期を通じて初期餌料生物が 豊富に存在する「Match」の状態を仔魚が経験し高成長 を遂げていた。以上の結果は，サワラではわずか 10 日 間（拱餌開始後 5 日間）の仔魚期に遭遇する餽料生物 環境がその後の成長・生残を大きく左右することを意味 している。これまで「Match-mismatch Hypothesis」 は, 生活史初期に無脊椎動物プランクトンを主食とする 魚種の加入変動を説明するために提唱されてきたもので あった。一連の研究成果にもとづいて, 強い魚食性を示 すサワラの加入変動を説明する際にこの仮説を適用でき る可能性が高いことを強調したい。38)

\section{5. Ł゙うなる？ 今後のサワラ資源}

瀬戸内海におけるサワラ漁獲量は 1986 年に $6000 \mathrm{t}$ 上回りピークに達した後減少を続け，1998 年に $200 \mathrm{t}$ 以下に低下した。近年は資源回復を目的とした人工種苗 の放流が行われ，漁獲量が増加に転じている。39) サワラ 資源変動の要因として, 漁獲圧, 水温等の物理環境との 関連などが指摘されている。 ${ }^{23,40)}$ また，本種と同様に高 位の捕食者に位置づけられるタチウオの漁獲量との間に 負の相関関係が認められている。 ${ }^{41)}$ 本報の結びとして, 初期飷料生物として重要なカタクチイワシ等ニシン目魚 類の再生産動向がサワラの加入に強い影響力を持つ可能 性を提案したい。サワラ資源が減少の一途をたどり始め た 1980 年代半ば以降, 瀬戸内海中央部に打いてマイワ シが再生産しはじめるとともに, ${ }^{42)}$ ニシン目魚類の種組 成に変化が認められた。(3,44) 嬘灘では, 初期饂料生物と して重要なカタクチイワシの 5 月に打ける産卵量が大 きく減少し, ${ }^{45)} 1990$ 年代にはサワラの初期飭料生物環 境が悪化していたと考えられる。摄餌開始期から魚類を 専食するサワラにとって, 仔魚慨料の分布密度の低下は 致命的となる。初期䬣料生物として重要なカタクチイワ シ等ニシン目魚類の再生産状況の変動に伴うボトム・ア ップ的メカニズムがサワラの加入を左右している可能性 が高いと考える。

\section{謝辞}

本研究の端緒から御指導と御助言を賜った京都大学つ ィールド科学教育研究センター田中 克先生, 終始打励 まし頂き討論に加わっていただいた田川正朋先生, 中山 耕至先生ならびに河口域生態学分野スタッフ, 舞鶴水産 実験所の山下 洋先生, 益田玲爾先生に心より御礼申し 上げる。フィールド調查を進めるに際し甚大なる御理解 々御協力をいただいた愛媛県中予水産試験場東予分場の 伊藤捷久場長, 前原 務氏, 広島県水産試験場の高場 稔場長, 旧南西海区水産研究所の岸田達氏, 瀬戸内海 区各府県水産試験場の資源担当者ならびに各地の漁業協 同組合の皆様に厚く御礼申し上げる。

\section{文献}

1) Houde ED. Fish early life dynamics and recruitment variability. Am. Fish. Soc. Symp. 1987; 2: 17-29.

2) Hunter JR. Feeding ecology and predation of marine fish larvae. In: Lasker R (ed) Marine Fish Larvae. Univ. Washington Press, Seattle. 1981; 32-77.

3) Keast A. The piscivore feeding guild of fishes in small freshwater ecosystems. Env. Biol. Fish. 1985; 12: 119129.

4) Sheldon, RW, Prakash A, Sutcliffe Jr WH. The size distribution of particles in the ocean. Limn. Oceanogr. 1972; 17: 327-340.

5) Tanaka M, Kaji T, Nakamura Y, Takahashi Y. Developmental strategy of scombrid larvae: high growth potential related to food habits and precocious digestive system development. In: Watanabe Y, Yamashita Y, Oozeki Y (eds) Survival strategies in early life stages of marine resources, A. A. Balkema, Rotterdam. 1996; 125-139.

6) Shoji J, Tanaka M. Strong piscivory of Japanese Spanish mackerel larvae from their first feeding. J. Fish. Biol. 2001; 59: 1682-1685.

7) Shoji J, Maehara T, Aoyama M, Fujimoto H, Iwamoto A, Tanaka M. Daily ration of Japanese Spanish mackerel Scomberomorus niphonius larvae. Fish. Sci. 2001; 67: 238245.

8) Shoji J, Aoyama M, Fujimoto H, Iwamoto A, Tanaka M. Susceptibility to starvation by piscivorous Japanese Spanish mackerel Scomberomorus niphonius (Scombridae) larvae at first feeding. Fish. Sci. 2002; 68: 59-64.

9) Cushing DH. Plankton production and year-class strength in fish populations: an update of the Match/mismatch Hypothesis. Adv. Mar. Biol. 1990; 26: 249-293.

10) Shoji J, Kishida T, Tanaka M. Piscivorous habits of Spanish mackerel larvae in the Seto Inland Sea. Fish. Sci. 1997; 63: 388-392.

11) Shoji J, Maehara T, Tanaka M. Short-term occurrence and rapid growth of Spanish mackerel larvae in the central waters of the Seto Inland Sea, Japan. Fish. Sci. 1999; 65: 68-72.

12) Young JW, Davis TLO. Feeding ecology of larvae of southern bluefin, albacore and skipjack tunas (Pisces: Scombridae) in the eastern Indian Ocean. Mar. Ecol. Prog. Seri. 1990; 61: 17-29.

13) Shoji J, Maehara T, Tanaka M. Comparative diets and 
growth of two scombrid larvae, chub mackerel Scomber japonicus and Japanese Spanish mackerel Scomberomorus niphonius, in the central Seto Inland Sea, Japan. UJNR Tech. Rep. 2003; 30: 93-103.

14) Shoji J, Tanaka M. Feeding of piscivorous Japanese Spanish mackerel juveniles on larvae with an elongate and laterally compressed body. J. Fish Biol. 2004; 65: 282286.

15) Sha $X, H e ~ G$, Chang H. A description of the morphological characters of the eggs and larvae of the blue spotted mackerel Scomberomorus niphonius (Cuvier \& Valenciennes). 海洋与湖沼. 1966; 8: 1-12.

16）樋口正毅，大島泰雄. 瀬戸内海におけるサワラとその種 苗放流に関する予察. 栽培技研 1974; 3: 43-60.

17）福永辰広, 石橋矩久, 三橋直人. サワラの採卵および種 苗生産. 栽培技研 1982; 11: 29-48.

18）沖山宗雄(編).「日本産稚魚図鑑」東海大学出版会, 東 京. 1988; 1154pp.

19) Scharf FS, Buckel JA, Juanes F, Conover DO. Predation by juvenile piscivorous bluefish (Pomatomus saltatrix): the influence of prey to predator size ratio and prey type on preadtor capture success and prey profitability. Can.J. Fish. Aquat. Sci. 1998; 55: 1695-1703.

20) Shoji J, Tanaka M. Daily ration and prey size of juvenile piscivore Japanese Spanish mackerel. J. Fish Biol. 2005; 67: in press.

21) Houde ED, Zastrow CE. Ecosystem- and taxon-specific dynamic and energetics properties of larval fish assemblages. Bull. Mar. Sci. 1993; 53: 290-335.

22) Houde ED. Comparative growth, mortality, and energetics of marine fish larvae: temperature and implied latitudinal effects. Fish. Bull. 1989; 87: 471-495.

23) Kishida T. Fluctuations in year-class strength of Japanese Spanish mackerel in the central Seto Inland Sea. Nippon Suisan Gakkaishi. 1991; 57: 1103-1109.

24) Shoji J, Maehara T, Tanaka M. Diel vertical movement and feeding rhythm of Japanese Spanish mackerel larvae in the central Seto Inland Sea. Fish. Sci. 1999; 65: 726730 .

25) Hunter JR, Kimbrell CA. Early life history of Pacific mackerel, Scomber japonicus. Fish. Bull. 1980; 78: 89101.

26) Shoji J, Maehara T, Tanaka M. Larval growth and mortality of Japanese Spanish mackerel (Scomberomorus niphonius) in the central Seto Inland Sea, Japan. J. Mar. Biol. Assoc. UK. 2005; 85: in press.

27) Shoji J, Tanaka M. Distribution, feeding condition, and growth of Japanese Spanish mackerel (Scomberomorus niphonius) larvae in the Seto Inland Sea. Fish. Bull. 2005; 103: 371-379.

28) Margulies D. Assessment of the nutritional condition of larval and early juvenile tuna and Spanish mackerel (Pisces: Scombridae) in the Panama Bight. Mar. Biol.
1993; 115: 317-330.

29) Fukuhara O. Morphological and functional development of Japanese flounder in early life stage. Nippon Suisan Gakkaishi 1986: 52: 81-91.

30) Shoji J, Masuda R, Yamashita Y, Tanaka M. Effect of low dissolved oxygen concentrations on behavior and predation rates on red sea bream Pagrus major larvae by the jellyfish Aurelia aurita and by juvenile Spanish mackerel Scomberomorus niphonius. Mar. Biol. 2005; 147: in press.

31) Masuda R, Shoji J, Aoyama M, Tanaka M. Chub mackerel larvae fed fish larvae can swim faster than those fed rotifers and Artemia nauplii. Fish. Sci. 2002; 68: 320-324.

32) Shoji J. Early survival strategies of Japanese Spanish mackerel (Scomberomorus niphonius) in the Seto Inland Sea. PhD Thesis, Kyoto University, Kyoto. 2000.

33）小路 淳. 瀬戸内海中央部の一漁港に打いて灯火採集に より得られた魚類幼稚仔. 南紀生物 2000; 42: 119-122.

34）小路 淳, 田中 克. 瀬戸内海中央部遂灘の砕波帯にお いて採集された魚類稚仔. 水産増殖 2002; 50: 123-128.

35）小路 淳, 前原 務, 武智昭彦, 谷川貴之, 村田憲之, 田中 克. 瀬戸内海中央部の遂灘に打いて採集された仔 稚魚. 日水誌 $2002 ; \mathbf{6 8}: 835-842$.

36) Shoji J, Maehara T, Tanaka M. Recruitment of an inherent piscivore, Japanese Spanish mackerel Scomberomorus niphonius (Scombriae). Fish. Sci. 2002; 68 (Sup. I): 218221.

37) Shoji J, Tanaka M. Effects of prey concentration on growth of piscivorous Japanese Spanish mackerel Scomberomorus niphonius larvae in the Seto Inland Sea, Japan. J. Appl. Ichthyol 2004; 20: 271-275.

38) Shoji J, Tanaka M. Larval abundance, growth, and recruitment of Japanese Spanish mackerel Scomberomorus niphonius in the Seto Inland Sea. In: Browman H, Sliftesvik $\mathrm{AB}$ (eds) The Big Fish Bang. Institute of marine Research, Bergen. 2003; 395-404.

39）滝本真一. 瀬戸内海西部海域のサワラ資源回復を目指し て.さいばい 2002; 104: 7-13.

40）河野悌昌, 花村幸生, 西山雄峰, 福田雅明. 瀬戸内海西 部におけるサワラ資源の年齢組成の変化. 南西水研報 1997; 30: 1-8.

41）浜田尚雄. 近年の瀬戸内海における漁海況の趨勢-II. 水 産海洋研究会報 1988; 52: 76-85.

42）橋本博明, 岡島静香, 角田俊平. イワシパッチ網の漁獲 物とカタクチイワシをめぐる魚類の漁獲量の動向. 広大 生物生産紀要 1989; 28: 79-92.

43）渡辺昭生, 塩田浩二, 西山雄峰. 愛媛県内海域における マイワシの漁獲動向. 南西外海の資源・海洋研究 1995; 11: 59-64.

44) Shoji J, Maehara T, Tanaka M. Two spawning seasons of the Japanese sardine in Hiuchi-nada, the central Seto Inland Sea. Fish. Sci. 1999; 65: 784-785.

45）愛媛県中予水産試験場, 愛媛県水産試験場. 平成 5 年度 漁海況予報事業結果報告書. 1996; 145. 